\title{
Editorial
}

\section{Editorial da Revista Ensaio 51}

A apresentação da Revista Ensaio: Avaliação e Políticas Públicas em Educação, $n^{\circ} 51$, é para nós motivo de grande satisfação, trazendo-nos a certeza da colaboração que os textos nela contidos irão prestar aos estudiosos da Educação, considerando a atualidade das informações, bem como a fundamentação apresentada por seus autores.

A presente publicação nos traz cinco artigos e duas sessões Página Aberta e Pesquisa em Síntese - que têm como referências pesquisas realizadas em âmbito nacional, levantando, primordialmente, questões atuais, enfocando, de forma diversificada, a Avaliação e as Políticas Públicas, temas de grande importância e alto interesse no presente momento.

No artigo primeiro, intitulado "Como está a educação no Brasil? O que fazer?" Ruben Klein mostra como está a Educação Brasileira em termos de atendimento, fluxo escolar e qualidade de ensino, sugerindo algumas ações, as quais, na visão do autor, terão efeito positivo sobre o fluxo e sobre o desempenho dos alunos.

Vera Werneck, no artigo intitulado "Sobre o processo de construção do conhecimento: o papel do ensino e da pesquisa", discorre acerca de um dos maiores obstáculos ao desenvolvimento do conhecimento humano, advindo da imprecisão dos termos utilizados na construção dos saberes e sobre os transtornos e as inadequações geradas por tal imprecisão, ocasionando graves conseqüências à formação desse processo de construção do conhecimento.

Tendo como ponto de partida a análise do Primeiro Congresso Mineiro de Educação, Magali de Castro aborda, no artigo "O estabelecimento de políticas educacionais através de consulta às bases: revisitando a proposta do Primeiro Congresso Mineiro de Educação", o hiato existente, segundo a autora, no que dizem as bases, quando têm a oportunidade de opinar em eventos como o que serviu de apoio para este estudo, e até onde estas opiniões são consideradas na elaboração dos documentos, nos discursos e nas iniciativas oficiais. 
O texto "Uma análise avaliativa de atitudes de estudantes de Ciências Contábeis e dilemas éticos sob uma perspectiva de gênero, maturidade acadêmica e ambiente institucional", se atém ao registro de uma investigação, girando em torno do comportamento ético em uma atividade que tem, em seu cotidiano, a vivência de conflitos ocorridos entre os diversos grupos de agentes econômicos. Esta é a temática apresentada por Jorge Expedito de Gusmão Lopes, José Francisco Ribeiro Filho, Marco Túllio de Castro Vasconcelos e Marcleide Maria Macêdo Pederneiras.

Tendo como objetivo analisar o caso educacional de adolescentes moradores em favelas, alunos da rede municipal do Rio de Janeiro, Ignez Martins Tollini, em seu artigo "Liderança e mudança: o caso educacional de jovens moradores de favelas", discute a situação desses alunos e apresenta propostas, com vistas à criação de Políticas Públicas voltadas para este tipo de população.

A sessão Página Aberta nos traz o "Projeto Eureka: a implantação da informática educativa na rede municipal de Campinas no período de 1989 - 1997", da autoria de Karina Soledad Maldonado Molina Pagnez, registrando a avaliação de um projeto que introduziu o computador na escola, como ferramenta pedagógica relacionada à formação e ao trabalho do professor em sala de aula.

A Pesquisa em Síntese apresenta "A contribuição da disciplina de introdução à engenharia química no diagnóstico da evasão" da autoria de Rosenir Rita de Cássia Moreira da Silva, Fernando Benedicto Mainier e Fabio Barboza Passos, analisando um sério problema ocorrente entre alunos dos Cursos de Graduação em Engenharia no país, o qual consiste nas altas taxas de evasão em conseqüência de diversos fatores, que são mencionados pelos autores, bem como, as possíveis alternativas para a melhoria do presente quadro.

Acreditamos que as abordagens desenvolvidas nos textos publicados nesta edição possam oferecer um rico e diversificado panorama sobre os estudos que estão sendo desenvolvidos nas Áreas de Avaliação e de Políticas Públicas em Educação. Na oportunidade, queremos agradecer aos autores deste número os quais, submetendo seus trabaIhos, com vistas à publicação em nossa Revista, colaboraram, grandemente para a disseminação do conhecimento e da informação educacional, dividindo com nosso público-leitor suas produções científicas. 